\title{
Distribution and fluctuations of backswimmers (Notonectidae) in a tropical shallow lake and predation on microcrustaceans
}

\author{
A. R. Domingos ${ }^{a}$ and M. S. Arcifa ${ }^{a}$ \\ ${ }^{a}$ Laboratório de Limnologia, Departamento de Biologia, Faculdade de Filosofia Ciências e Letras de Ribeirão Preto - \\ FFCLRP, Universidade de São Paulo - USP, Av. Bandeirantes, 3900, CEP 14040-901, Ribeirão Preto, SP, Brazil \\ *e-mail: andresrdomingos@usp.br
}

Received: July 16, 2015 - Accepted: October 16, 2015 - Distributed: February 28, 2017

(With 4 figures)

\begin{abstract}
Notonectids are widely distributed in freshwaters and can prey on zooplankton in temperate lakes. However, its role in structuring the zooplankton community is unknown in tropical lakes. Thus, our objective was to study the notonectid Martarega uruguayensis in a Brazilian tropical shallow lake to evaluate its potential as a zooplankton predator. Its horizontal distribution was analized in the lake throughout one year in fortnightly samplings. Backswimmers were more abundant (mean density $162.9 \pm 25.8$ ind. $\mathrm{m}^{-2}$ ) in the cool-dry season, with a strong preference by the littoral zone (mean density $139.9 \pm 17.5$ ind. $\mathrm{m}^{-2}$ ). Laboratory experiments were undertaken with young and adult notonectid and the two most abundant cladocerans, Daphnia gessneri and Ceriodaphnia richardi, as prey. Predation by backswimmers in the laboratory showed that only juveniles fed on microcrustaceans (mean ingestion rate of $1.2 \pm 0.2$ Daphnia and $1.0 \pm 0.2$ Ceriodaphnia per predator per hour), without size selectivity. Adult insects probably have difficulties in detecting and manipulating small planktonic organisms. On the other hand, young instars might influence zooplankton community, especially in the littoral zone of the lake. This study does contribute to a better understanding of trophic interactions in tropical shallow lakes and is the first to investigate the predation of a notonectid on microcrustaceans from Lake Monte Alegre.
\end{abstract}

Keywords: predation, Heteroptera, aquatic insects, zooplankton, Lake Monte Alegre.

\section{Distribuição e flutuação de notonectídeos (Notonectidae) em um lago tropical raso e a predação sobre microcrustáceos}

\section{Resumo}

Notonectídeos são amplamente distribuídos em águas continentais e podem predar zooplâncton em lagos temperados. Porém, seu papel na estruturação de comunidades zooplanctônicas é desconhecido em lagos tropicais. Então, nosso objetivo foi estudar o notonectídeo Martarega uruguayensis em um lago tropical raso brasileiro para avaliar seu potencial como predador do zooplâncton. Sua distribuição horizontal foi analisada no lago durante um ano em coletas quinzenais. Os notonectídeos foram mais abundantes (densidade média 162,9 $\pm 25,8$ ind. $\mathrm{m}^{-2}$ ) na estação fria-seca, com nítida preferência pela zona litorânea (densidade média 139,9 $\pm 17,5$ ind. $\mathrm{m}^{-2}$ ). Foram feitos experimentos de laboratório com jovens e adultos de notonectídeo e as duas espécies de cladóceros mais abundantes, Daphnia gessneri and Ceriodaphnia richardi, como presas. No laboratório, somente os jovens predaram os microcrustáceos (taxa média de ingestão 1,2 \pm 0,2 Daphnia e 1,0 \pm 0,2 Ceriodaphnia por predador por hora), sem haver seletividade. Os insetos adultos provavelmente têm dificuldade em detectar e manipular pequenos organismos planctônicos. Por outro lado, os estádios jovens podem influenciar a comunidade zooplanctônica, especialmente na zona litorânea do lago. Esse estudo contribui para uma melhor compreensão sobre interações tróficas em lagos tropicais rasos e é o primeiro a investigar a predação de um notonectídeo sobre microcrustáceos do Lago Monte Alegre.

Palavras-chave: predação, Heteroptera, insetos aquáticos, zooplâncton, Lago Monte Alegre.

\section{Introduction}

Predation in lentic ecosystems is one of the most important ecological interactions directly influencing zooplankton community structure (Hall et al., 1970; Zaret, 1980; Kerfoot and Sih, 1987; Arner et al., 1998). The role of predation in prey communities would depend on many factors, such as the joint effect of vertebrate and invertebrate predators, duration of predation pressure, prey size, density of predators and prey selectivity (Brooks and Dodson, 
1965; Brooks, 1968; Hall et al., 1976; Peckarsky, 1982; Hanazato and Yasuno, 1989; Eitam and Blaustein, 2010). In addition, predators can influence prey communities, not only by direct effects of consumption, but also through sub lethal effects, such as injuries that might kill prey.

The aquatic insects known as backswimmers (Heteroptera: Notonectidae) are invertebrate predators that can play a major role in shaping the structure and the abundance of zooplankton population in several freshwater environments (Nesbitt et al., 1996; Blaustein, 1998; Hampton et al., 2000). They are mainly associated to the littoral areas with stands of macrophytes, although they can also inhabit the limnetic zone, as their distribution pattern depends on both biotic and abiotic factors (Bennett and Streams, 1986; Bailey, 1987; Streams, 1987a; Gilbert et al., 1999; Foltz and Dodson, 2009). Notonectids normally explore the water surface, although they are also able to dive to at least $0.5 \mathrm{~m}$ (Streams, 1992). They usually attack prey by grabbing them with their fore and mid legs, piercing them with the rostrum, and injecting digestive enzymes before sucking the inner content (Streams, 1987b). They have a broad diet that includes several aquatic organisms, such as rotifers, crustaceans, mosquito larvae, tadpoles and aquatic insects (Hirvonen, 1992; Blaustein, 1998; Gilbert and Burns, 1999; Hampton and Gilbert, 2001; Saha et al., 2010; Jara et al., 2012; Fischer et al., 2012, 2013). A few papers have shown that there is a decreased appetite associated with adults (Scott and Murdoch, 1983; Murdoch and Scott, 1984), while Gilbert and Burns (1999) showed the opposite. Furthermore, they often feed on terrestrial organisms trapped on the water surface that become vulnerable to predation, such as bees, ants, and mosquitos. Their ability and preference to feed on zooplankton and insect larvae have been observed in the laboratory (Murdoch and Sih, 1978; Sih, 1982; Scott and Murdoch, 1983; Murdoch et al., 1984; Murdoch and Scott, 1984; Streams, 1987b; Gilbert and Burns, 1999; Hampton and Gilbert, 2001; Walsh et al., 2006; Gergs and Ratte, 2009; Gergs et al., 2010; Saha et al., 2010; Fischer et al., 2012, 2013), in outdoor containers (Murdoch and Sih, 1978; Murdoch et al., 1984; Arner et al., 1998; Eitam and Blaustein, 2010) and natural habitats (Nesbitt et al., 1996; Blaustein, 1998; Hampton et al., 2000).

Most studies on invertebrate predation were carried out in temperate lakes, so new insight on tropical lakes may be of great interest to know the role of predation on the structuring of prey communities. Studies carried out on the biotic and abiotic aspects of the tropical shallow Lake Monte Alegre, in southeastern Brazil, resulted in the knowledge of the major factors involved in structuring the zooplankton community in this ecosystem. Predation by water mite (Cassano et al., 2002) and Chaoboridae larvae has emerged as the most important factor in structuring the zooplankton community (Arcifa et al., 1992, 2015; Arcifa, 2000; Castilho-Noll and Arcifa, 2007a, b), whose impact is stronger during the warm season (Arcifa et al., 1992, 2015), and influencing the vertical migration of microcrustaceans (Minto et al., 2010). However, there are other invertebrate predators that have never been studied in this environment and might affect zooplankton community, such as notonectids. Therefore, this study does contribute to a better understanding of the trophic interactions in tropical shallow lakes and also of the ecology of a notonectid.

This study is part of a larger project on interactions in the lake and the structuring of communities. The aim was to determine experimentally the potential predation of the young and adult backswimmer Martarega uruguayensis (Berg) on the most abundant and frequent zooplankton species in Lake Monte Alegre, the cladocerans Daphnia gessneri Herbst and Ceriodaphnia richardi Sars. Fluctuations of the backswimmer population, age structure, and spatial distribution were evaluated to detect periods and zones of the lake where predation upon microcrustaceans would be potentially more intense. The hypotheses are that predation of the young M. uruguayensis on the two cladoceran species would be more intense than predation by adults, and that the notonectid population is more abundant in the littoral zone, where it could exert a potentially higher predation pressure.

\section{Material and Methods}

\subsection{Study site}

Lake Monte Alegre ( $\left.21^{\circ} 10^{\prime} 04^{\prime \prime} \mathrm{S}, 47^{\circ} 51^{\prime} 28^{\prime \prime} \mathrm{W}\right)$ is a small, shallow, tropical and eutrophic reservoir (area $=7 \mathrm{ha}$, maximum depth $=5 \mathrm{~m}$; altitude $500 \mathrm{~m}$ a.s.l) (see Figure 1). It is located in southeastern Brazil, in the town of Ribeirão Preto (SP), inside the campus of the University of São Paulo. The reservoir was closed in 1942 by damming the Laureano Creek, which belongs to the Pardo River basin. The lake was used initially for irrigation and recreation, but since the 1980s it has been used for research and teaching, besides having an ornamental value. Although it is a reservoir, the functioning of Lake Monte Alegre is similar to a natural lake due to the lack of dam manipulation and a residence time relatively high for its dimensions ( $\sim 5$ days). Currently, the margins and surroundings are covered by dense terrestrial vegetation, mostly trees and herbaceous plants. The aquatic vegetation is predominantly composed of the emergent macrophyte Ludwigia sp., distributed in narrow stands and occupying some regions of the littoral area. The region has a tropical climate, with two well-defined seasons: warm-wet (October-April) and cool-dry season (May-September) (Arcifa et al., 1990). The only filter-feeder planktivore is the adult of the exotic cichlid Tilapia rendalli Boulenger, which is not abundant (Arcifa and Meschiatti, 1993). The main invertebrate predators are the dipteran Chaoborus brasiliensis Theobald, the water mite Krendowskia sp. and Martarega uruguayensis, which is the only notonectid specie.

\subsection{Field sampling}

Population fluctuations and spatial distribution of M. uruguayensis were studied in fortnightly samplings during one year, from December 2011 to December 2012. On each sampling event, backswimmers were collected in 
the littoral zone, near the edge of macrophytes ( $1 \mathrm{~m}$ deep with stands of Ludwigia sp.) and in the limnetic zone ( $5 \mathrm{~m}$ deep without macrophytes). Samplings were carried out by superficial sweeping with a dip net $(37 \times 28 \mathrm{~cm}$; $500 \mu \mathrm{m}$-mesh) in three longitudinal transects, $10 \mathrm{~m}$ long each, in both zones (see Figure 1). The transects were sufficiently separated to ensure independence of samples. After samplings, superficial water temperature was measured by a probe Yellow Springs ${ }^{\mathrm{TM}}{ }^{\circledR}$ Model 95 . Insects were preserved in ethanol $80 \%$ and individuals were counted to calculate the population densities in each date and were measured under a stereomicroscope to identify instars and the relative population abundance. The cladocerans used as prey in the experiments were collected with a plankton net (60 $\mu \mathrm{m}$-mesh) by three vertical hauls. They were cultivated at the laboratory to obtain a sufficient number of individuals for the experiments.

\subsection{Laboratory experiments}

Experiments were carried out in an environmental chamber (FANEM ${ }^{\mathrm{TM}}{ }^{\circledR}$, model CDG), at $25^{\circ} \mathrm{C}$ and diffuse light. Overall, four experimental assays were performed following general conditions and procedures as shown in Table 1. The culture of cladocerans after field samplings

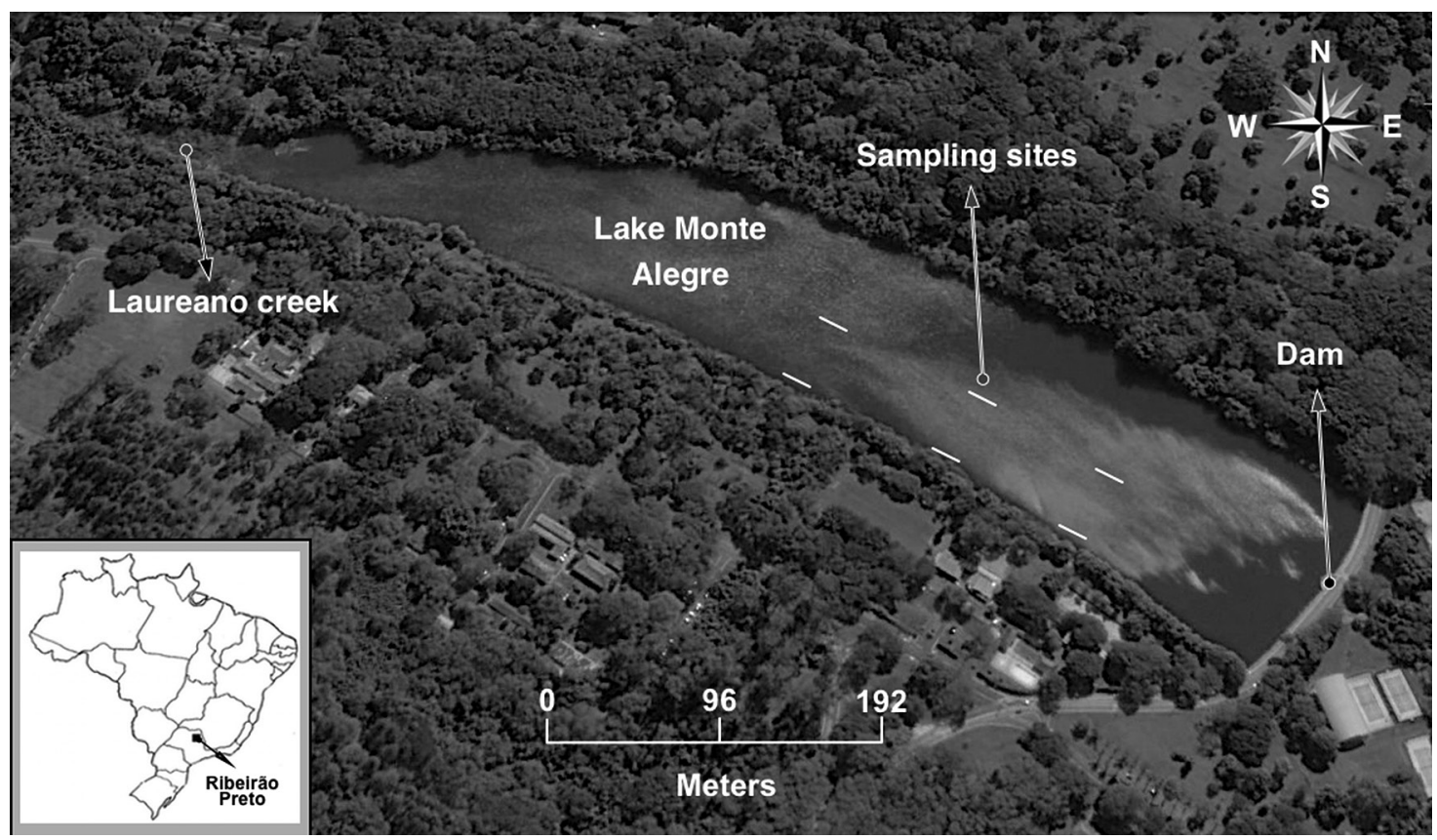

Figure 1. Map of Lake Monte Alegre. The sampling sites are transects of $10 \mathrm{~m}$ ( 3 in the littoral and 3 in the limnetic zone).

Table 1. Experimental conditions and the length (mean $\pm \mathrm{SD}$; mm) of species: Prey - Ceriodaphnia richardi and Daphnia gessneri; Predator - Martarega uruguayensis.

\begin{tabular}{|c|c|c|}
\hline \multicolumn{3}{|c|}{ Experimental conditions } \\
\hline Acclimation time & & 24 hours \\
\hline Temperature & & $25^{\circ} \mathrm{C}$ \\
\hline Containers & & $1800 \mathrm{ml}$ beakers \\
\hline$N^{0}$ of replicates & & 6 replicates \\
\hline $\mathrm{N}^{0}$ of predators & & 2 predators per replicate \\
\hline Initial density (ID) & & 20 prey per replicate \\
\hline Experimental time & & 2 hours \\
\hline \multirow{3}{*}{ Experiment 1} & Prey and length & Predator \\
\hline & D. gessneri & M. uruguayensis \\
\hline & $1.11 \pm 0.17$ & $6.58 \pm 0.19$ (adult) $\hat{\jmath} q$ \\
\hline \multirow[t]{2}{*}{ Experiment 2} & C. richardi & M. uruguayensis \\
\hline & $0.72 \pm 0.08$ & $6.62 \pm 0.16$ (adult) ${ }^{\lambda} ᄋ$ \\
\hline \multirow[t]{2}{*}{ Experiment 3} & D. gessneri & M. uruguayensis \\
\hline & $1.14 \pm 0.17$ & $3.02 \pm 0.21$ (juvenile) \\
\hline \multirow[t]{2}{*}{ Experiment 4} & C. richardi & M. uruguayensis \\
\hline & $0.61 \pm 0.05$ & $3.32 \pm 0.39$ (juvenile) \\
\hline
\end{tabular}


was carried out in glass bottles attached to a plankton wheel, with addition of $1 \mathrm{mgC} . \mathrm{L}^{-1}$ of the chlorophycean Desmodesmus spinosus (Chodat) (former Scenedesmus spinosus) every other day. The backswimmers used in the experiments, collected with a dip net described in the previous section, were kept at the laboratory in the environmental chamber, in $80 \mathrm{~mL}$ beakers filled with filtered lake water (glass fiber, Millipore ${ }^{\mathrm{TM}}{ }^{\circledR}$ AP20). They were deprived of food for $24 \mathrm{~h}$ prior to the experiments, for standardizing the level of hunger. Feeding trials were set up separately to analyze the consumption of cladocerans by young and adult instars of the notonectid. In each experiment, only one species of prey was used. We set two experimental treatments with six replicates each: 1 . predator + prey $(\mathrm{P}+)$; and 2. control with prey only (P-). Each replicate contained 20 prey as Initial Density (ID) and 2 predators in $(\mathrm{P}+$ ) treatment (according to Scott and Murdoch, 1983; Cassano et al., 2002). Densities in the experimental trials were close to low densities found for Martarega $\left(38\right.$ ind. $\left.\mathrm{m}^{-2}\right)$ and microcrustaceans (10 ind. $\left.\mathrm{L}^{-1}\right)$ in the lake.

After the acclimation time, the notonectids were placed in $1800 \mathrm{~mL}$ beakers filled with $500 \mathrm{~mL}$ of filtered lake water. Then, $1 \mathrm{mgC} . \mathrm{L}^{-1}$ of $D$. spinosus was added to the beakers as food for cladocerans, and they were arranged in a systematic way to avoid pseudoreplication (Hurlbert, 1984). After 2 hours, predators were removed from the beakers and the following variables were evaluated: Intact Prey (IP), Natural Prey Death (NPD), Experimental Error (EE) and Ingestion Rate (IR). IP represents the individuals that were alive and NPD the individuals that died without any predator influence. These individuals are easily recognizable because they have no damages, such as crushed carapace or holes, and the internal parts are intact. EE was calculated only for (P-) treatments and it represents mean error in prey counting after experiment ends, since the number of individuals in (P-) should be the same at the beginning and the end of the experiment; it was calculated by the Initial Density (ID) minus Intact Prey (IP) in the control treatment (P-). The estimated IR of prey eaten per predator per hour was calculated following Gilbert and Burns (1999) (Equation 1):

$$
I R=I P c-I P e / T \times N
$$

where (IPc) is the Intact Prey in the control treatment (P-), (IPe) is the Intact Prey in the experimental treatment with predators $(\mathrm{P}+),(\mathrm{T})$ is time in hours and $(\mathrm{N})$ is the number of predators in the treatments.

\subsection{Statistical analyses}

The mean densities of M. uruguayensis in the littoral and limnetic zones and in the warm-wet and cool-dry seasons were compared by the non-parametric Mann-Whitney test. One-way analysis of variance (ANOVA) was applied to compare the mean relative abundance of instars (I to VI) during the whole period in the lake. To determine the size of the instars, a histogram was built with the frequency of each size class of the notonectid using the collections in the field. Thus, the histogram peaks corresponded to the size of each instar. The dispersion index $\left(D I=\sigma^{2} / \mu\right)$ was used to infer notonectid natural aggregation in each lake zone and sampling period. The index was used to test the null hypothesis that the observed distribution pattern is random. The DI with $n-1$ degrees of freedom is approximately distributed as $\chi^{2}$, small values meaning random distribution while large values $(\geq 5.99 ; P \leq 0.05)$ indicate aggregation.

Mann-Whitney test was used to compare IP and NPD between the treatments $(\mathrm{P}+)$ and $(\mathrm{P}-)$, and Kruskal-Wallis was applied to compare EE between experiments (1 to 4). Two-way analysis of variance (ANOVA) was used to test differences in IR of young and adult predators on prey species ( $C$. richardi and D. gessneri). All statistical analyses were conducted using the software Statistica ${ }^{\text {TM }}{ }^{\circledR}$ 8.0 at significance level of $95 \%$.

\section{Results}

\subsection{Fluctuations, spatial distribution and age structure of Martarega uruguayensis}

In the littoral zone, the highest densities of M. uruguayensis occurred during the cool season (mean surface temperature $23.7 \pm 1.2^{\circ} \mathrm{C}$ ) and the lowest density occurred in the warm season (mean surface temperature $28.8 \pm 1.3{ }^{\circ} \mathrm{C}$ ) (see Figure 2). The mean density of the insects in the cool season $\left(162.9 \pm 25.8\right.$ ind $\left.\mathrm{m}^{-2}\right)$ was significantly higher than in the warm season $\left(87.3 \pm 14.7\right.$ ind. $\mathrm{m}^{-2}$ ) (Mann-Whitney, $U=39.00, P=0.02)$. High values of standard error of the means may be explained by insect aggregation in the environment, resulting in high density variations among replicates. In the limnetic zone, densities were almost nil in all periods (see Figure 2). A significant higher mean density of backswimmers was found in the littoral $\left(139.9 \pm 17.5\right.$ ind $\left.\mathrm{m}^{-2}\right)$ compared with the limnetic zone $\left(0.05 \pm 0.01\right.$ ind. $\left.\mathrm{m}^{-2}\right)$ (Mann-Whitney, $\left.U=0.00, P=0.00\right)$.

The trend in age structure was similar during the whole sampling period (see Figure 3). Adults comprised a significant percentage of the population sampled through the year. The mean relative abundance of adults ranged from $39.0 \pm 3.3 \%$ to $65.8 \pm 5.7 \%$. For the other instars the mean relative abundance ranged from $0.2 \pm 0.2 \%$ to $22.2 \pm 1.4 \%$. There were significant differences among the relative abundances of the instars (ANOVA, F 5, $210=215.9$, $P=0.00)$, the adult means differing from all the means of young instars (Tukey HSD, $P=0.00$ ).

In the littoral zone, backswimmers were aggregated in all the sampling dates, with the dispersion index (DI) ranging from 20.7 to 1457.0 . In the limnetic zone, there was a trend to random distribution in all the samplings, DI ranging from 1.0 to 2.0.

\subsection{Laboratory experiments}

We counted the number of Intact Prey (IP), Natural Prey Death (NPD) and also calculated the Experimental Error (EE) and Ingestion Rate (IR) at the end of the experiments (as shown in Table 2). The average numbers of IP between the treatments of the experiment 1 (D. gessneri vs. adult 


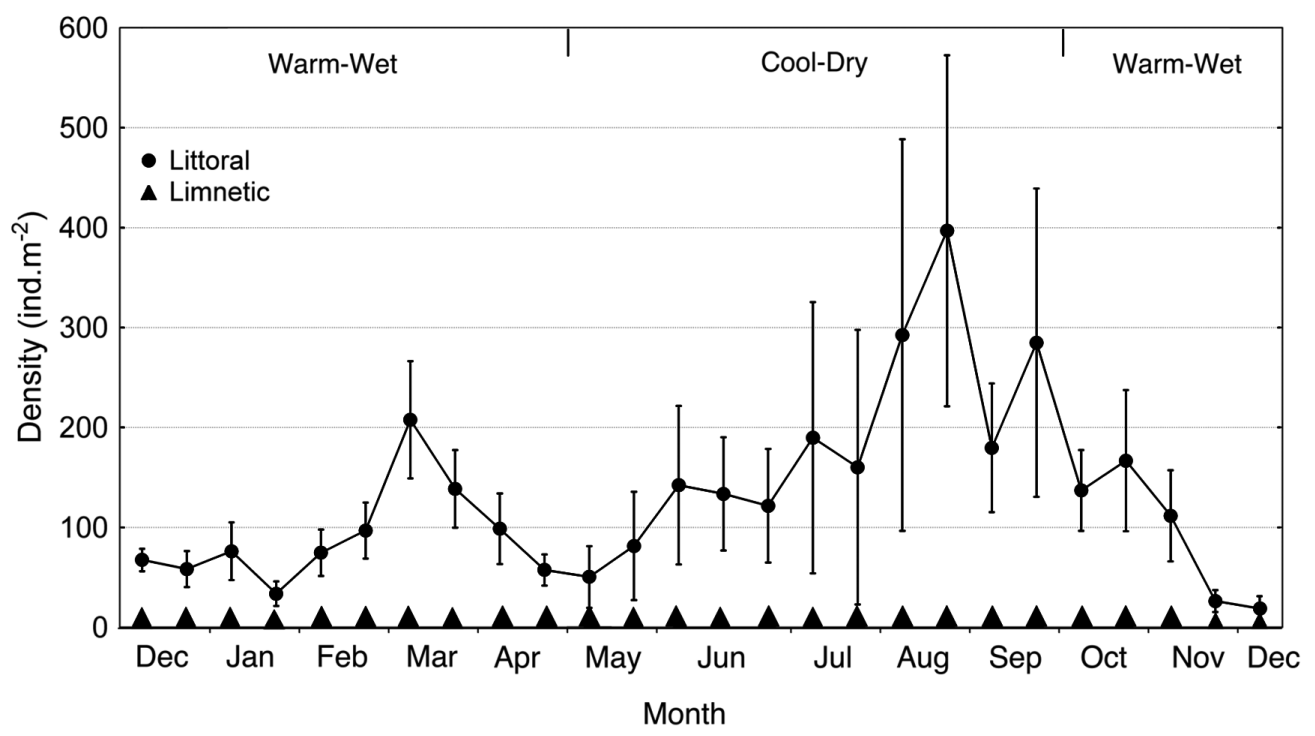

Figure 2. Density (mean \pm SE) of Martarega uruguayensis in the littoral and limnetic zones, during 12 months and fortnightly samplings.

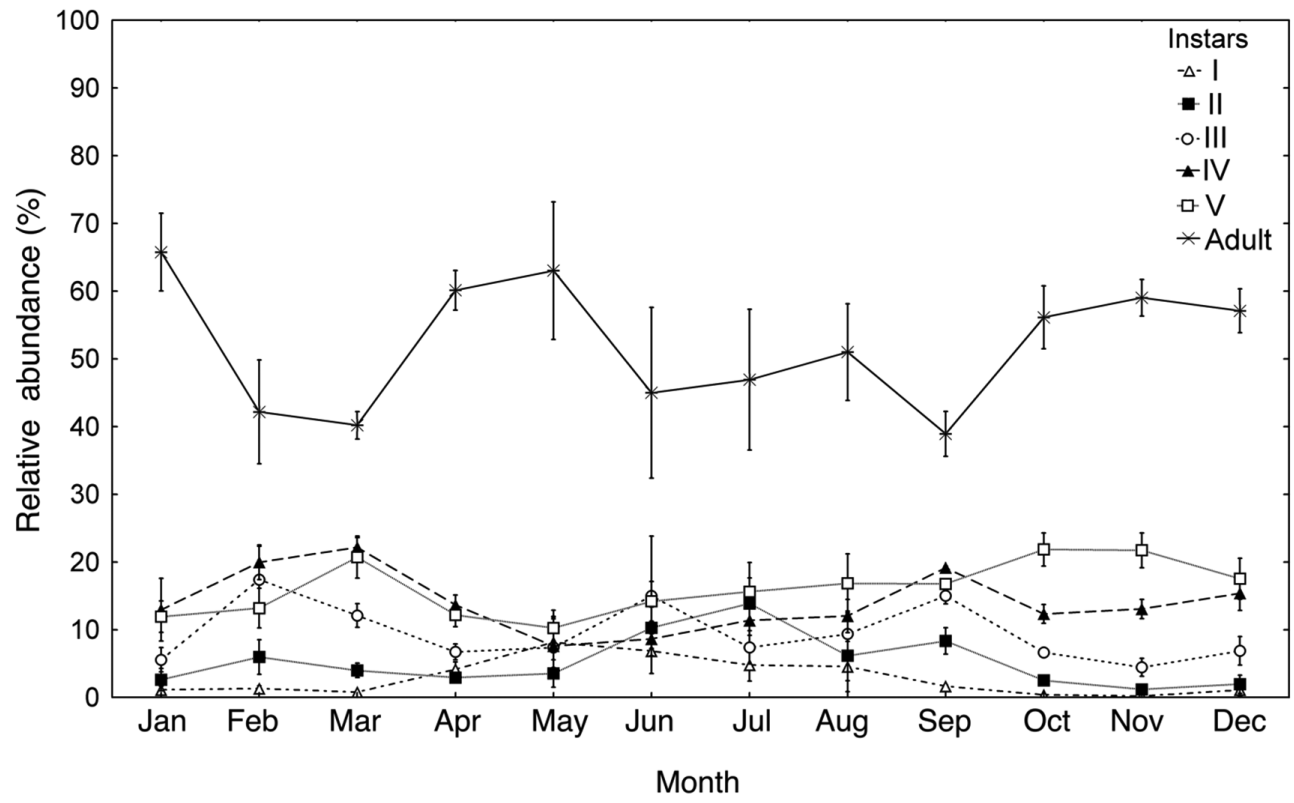

Figure 3. Relative abundance (mean \pm SE) of instars I, II, III, IV, V, and adult Martarega uruguayensis, during 12 months.

Table 2. Mean ( \pm SE) values of the variables Experimental Error (EE) (ind/replicate), Natural Prey Death (NPD) (ind/replicate), Intact Prey (IP) (ind/replicate) and Ingestion Rate (IR) (prey. pred. ${ }^{-1} \mathrm{~h}^{-1}$ ) in the treatment $(\mathrm{P}+)$ containing predator and prey and in the treatment (P-) containing only prey.

\begin{tabular}{|c|c|c|c|c|c|c|c|c|}
\hline \multirow{2}{*}{ Experiment } & \multirow{2}{*}{ Instar } & \multirow{2}{*}{ Prey } & \multirow{2}{*}{$\begin{array}{c}\text { EE } \\
\text { P- } \\
\end{array}$} & \multicolumn{2}{|c|}{ NPD } & \multicolumn{2}{|c|}{ IP } & \multirow{2}{*}{$\begin{array}{l}\text { IR } \\
\text { P+ }\end{array}$} \\
\hline & & & & P- & $\mathbf{P}+$ & P- & $\mathbf{P}+$ & \\
\hline 1 & Adult & Daphnia & $0.3 \pm 0.2$ & $0.3 \pm 0.2$ & $0.5 \pm 0.3$ & $19.7 \pm 0.2$ & $19.2 \pm 0.5$ & $0.1 \pm 0.1$ \\
\hline 2 & Adult & Ceriodaphnia & $0.3 \pm 0.2$ & $0.2 \pm 0.2$ & $0.3 \pm 0.3$ & $19.7 \pm 0.2$ & $19.7 \pm 0.2$ & $0.0 \pm 0.1$ \\
\hline 3 & Juvenile & Daphnia & $0.3 \pm 0.2$ & $0.8 \pm 0.3$ & $0.8 \pm 0.3$ & $19.7 \pm 0.2$ & $15.2 \pm 1.0$ & $1.2 \pm 0.2$ \\
\hline 4 & Juvenile & Ceriodaphnia & $0.5 \pm 0.2$ & $0.3 \pm 0.2$ & $0.2 \pm 0.2$ & $19.5 \pm 0.2$ & $15.5 \pm 0.8$ & $1.0 \pm 0.2$ \\
\hline
\end{tabular}


notonectid) and 2 (C. richardi vs. adult notonectid) were not significantly different. In the experiment 3 (D. gessneri vs. young notonectid), and 4 (C. richardi vs. young notonectid), the average number of IP in the (P-) treatment was statistically different from that of $(\mathrm{P}+)$ treatment (Mann-Whitney, $U=0.0, P=0.00$ for both). The effect of the predator instar (adult and juvenile) and the prey species (large Daphnia gessneri and medium-sized Ceriodaphnia richardi) on the IR showed that young instars significantly preyed on both cladocerans (see Figure 4). There was no effect of prey species on predator IR, and young instars fed on similar number of $D$. gessneri and C. richardi (as shown in Table 3 ).

Occasionally, cladocerans died naturally without any evidence of predator attack. Such individuals did not represent a problem in estimating IP, since they were easily recognized (conspicuous milky appearance with intact outer and inner structures). Natural Prey Death (NPD) occurred in all experiments and did not differ between the treatments

Table 3. Two-way ANOVA for effects of predator instar (juvenile and adult) and prey species (Daphnia gessneri and Ceriodaphnia richardi) on the ingestion rate (IR) of Martarega uruguayensis.

\begin{tabular}{lcccc}
\hline \multicolumn{1}{c}{ Source } & d.f. & M.S. & $\boldsymbol{F}$ & $\boldsymbol{P}$ \\
\hline Instar & 1 & 6.77 & 37.1 & 0.00 \\
Prey & 1 & 0.12 & 0.71 & 0.41 \\
Instar*Prey & 1 & 0.00 & 0.01 & 0.90 \\
Error & 20 & 0.17 & & \\
\hline
\end{tabular}

$(\mathrm{P}+)$ and $(\mathrm{P}-)$ for any experiment (as shown in Table 2). In the control treatments, the EE was null in $62.5 \%$ of the replicates, and there was no statistical difference (Kruskal Wallis, $H=0.51, P=0.91$ ) comparing the mean EE among all the four experiments (as shown in Table 2).

\section{Discussion}

The hypothesis that a higher population densities of notonectids would be found in the littoral zone of the Lake Monte Alegre was confirmed, agreeing with other studies that have shown that backswimmers tend to occupy the littoral zone where aquatic vegetation is abundant (Bennett and Streams, 1986; Bailey, 1987; Gilbert et al., 1999). Significant factors that affect the distribution of backswimmers are the habitat size, amount of shade, depth, substrate type, water temperature, characteristics of macrophytes, presence of predator and prey diversity (Giller and McNeill, 1981; Foltz and Dodson, 2009; Schilling et al., 2009). Prey abundance and diversity is a plausible hypothesis in Lake Monte Alegre, since the diversity of microhabitats in the littoral and the proximity of the terrestrial environment can provide a greater supply of resources than the limnetic zone, which might explain the notonectid preference by the littoral. Littoral harbor a large variety of potential prey from the terrestrial habitat, such as insects that fall on the water, becoming vulnerable to predation (A.R. Domingos pers. obs). In the littoral, invertebrates are also abundant within macrophyte stands (Meschiatti and Arcifa, 2002), besides planktonic organisms

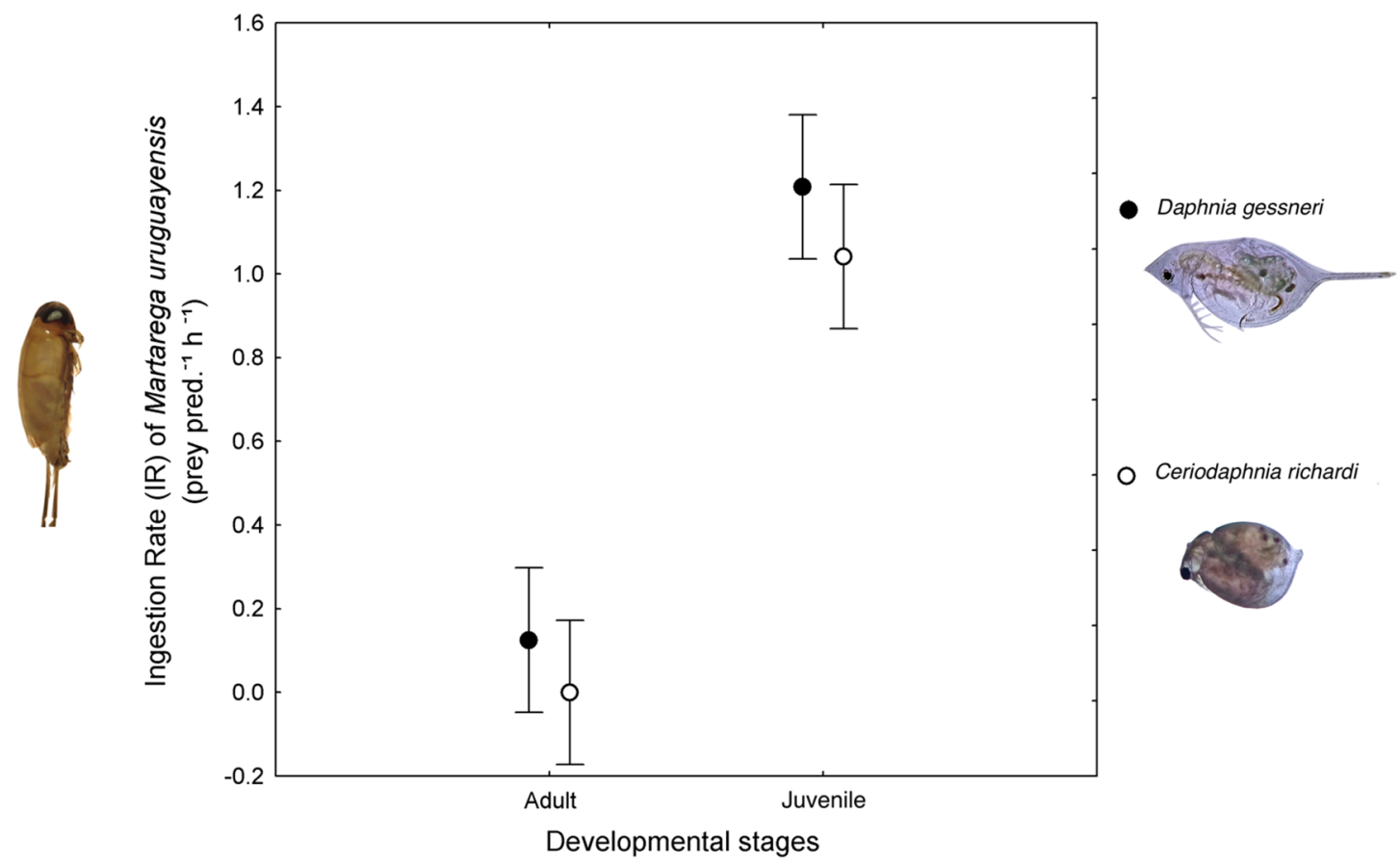

Figure 4. Ingestion rate (IR) (mean $\pm \mathrm{SE}$ ) of the cladocerans Daphnia gessneri and Ceriodaphnia richardi by young and adult Martarega uruguayensis. 
at their edge (Arcifa et al., 2013) and in the benthos of shallow areas (Cleto-Filho and Arcifa, 2006). Another aspect is that backswimmers are distributed near the upper layer of the water (Streams, 1992) and, therefore, the shallow littoral zone would favor the search and capture of prey like cladocerans and other aquatic organisms inhabiting the water column. Macrophytes in the littoral also play an important role in the reproduction of backswimmers, since they can use the stems to lay eggs (Nessimian and Ribeiro, 2000). The aggregated distribution of the backswimmers in the littoral zone can occur by the quality of sites for oviposition, amount of prey, better conditions for refuge in macrophyte stands and anti-predatory behavior (Gilbert et al., 1999; Bailey, 1987, 2010). The occurrence of such aggregation explains the wide variation in abundance among our samples.

The predominance of older instars leads us to question on the microhabitat preference by different instars of the notonectids. As adults are always more abundant than all other instars it is possible that juveniles do not live in the same microhabitat of adults. Therefore, they were underrepresented in the samples due to a niche partition, and horizontal and vertical stratification between adults and juveniles. Maybe young instars are distributed within the macrophyte stands, instead of at their edge, where sampling was made. Several studies indicate that segregation between young instars and adults usually occurs for some species of notonectids, juveniles migrating to or remaining in areas with fewer adults (Murdoch and Sih, 1978; Sih, 1982; Bailey, 1987; Gilbert et al., 1999; Hampton, 2004). We were unable to sample quantitatively in the middle of macrophyte stands to compare to the sampling made at their edge, because superficial sweepings with a dip net in longitudinal transects were prevented by the macrophyte structure. However, we observed, without quantification, that in this microhabitat young instars were more frequent than adults. Therefore, due to limitations of the sampling method used, it was impossible to accurately detect juveniles at the sampling site, resulting in a higher relative frequency of adults.

The hypothesis that young M. uruguayensis would be a predator of the two planktonic species was confirmed, since only young instars effectively preyed on C. richardi and $D$. gessneri. Higher predation pressure by juveniles on Daphnia and Ceriodaphnia, in comparison to adults, was also found by another studies (Scott and Murdoch, 1983; Murdoch and Scott, 1984), differing from Gilbert and Burns (1999), who found that large instars of notonectids preyed on more cladocerans than small ones. Murdoch et al. (1984) also showed that adult Notonecta sp. preferred at least one size class of mosquito larvae than Ceriodaphnia sp. On the other hand, young instar of Notonecta sp. selected Ceriodaphnia sp. in relation to the other surface prey, such as Drosophila. Adult backswimmers are not morphologically adapted to feed on small prey (Ellis and Borden, 1970). Thus, they are likely to have greater facility in capturing prey larger than microcrustaceans, such as terrestrial insects on the water surface, aquatic insects and larvae (Quiroz-Martínez and Rodríguez-Castro, 2007; Fischer et al., 2012), which are abundant in the littoral zone of Lake Monte Alegre, such as Chironomidae (Cleto-Filho and Arcifa, 2006). But the capture of small sized microcrustaceans by adults do not worth the energy expenditure with the attack for greater difficulties of detection and handling, and the low nutritional content of prey.

There is strong evidence that prey size is a key factor for predator's preference in aquatic environments, leading to the generalization that aquatic invertebrate predators are size selective (Brooks and Dodson, 1965; Zaret, 1980). In fact, several authors observed that notonectids exhibit a tendency to select zooplanktonic prey based on their size, with a clear preference for the largest ones, indirectly favoring smaller and supposedly less competitive zooplankton species (Cooper, 1983; Scott and Murdoch, 1983; Murdoch and Scott, 1984; Gilbert and Burns, 1999; Walsh et al., 2006; Lindholm and Hessen, 2007; Gergs and Ratte, 2009). Blaustein (1998) showed that Notonecta was responsible for structuring the community by size selective predation, resulting in density reduction of larger Daphnia, without affecting the density of the smaller Ceriodaphnia. In our study, there was no size selective predation on the larger zooplankton prey offered (Daphnia), since no differences were observed in ingestion rates of $C$. richardi and $D$. gessneri by young $M$. uruguayensis. This result, which differs from other mentioned studies, may have been influenced by the structural simplicity of the experimental containers when compared to the lake conditions. The containers were small-sized and homogeneous, without refuge for prey. Since environmental heterogeneity can provide spatial refuges with reduced predation risk, the homogeneous environment could facilitate prey capture. Thus, any encounter of young instars with prey probably produced a stimulus, resulting in attacks, regardless of prey size. In this case, despite differences between the laboratory and lake conditions, these results show, at least qualitatively, the potential predation of $M$. uruguayensis on cladocerans (C. richardi and D. gessneri) from Lake Monte Alegre.

Another important issue is that the influence of Natural Prey Death was negligible in the experiments, so the effect of predators, which eventually could cause an imperceptible injury that would culminate in the prey death, was not detected in our study. Since the experimental error was constant, there was no interference on the experimental results.

In conclusion, this study contributed to enlarge the knowledge upon invertebrate predation on the zooplankton community of the tropical shallow Lake Monte Alegre and also on the ecology of notonectids. The younger individuals of $M$. uruguayensis potentially feed on the microcrustaceans $D$. gessneri and $C$. richardi in the lake. The predation pressure is concentrated in the littoral zone where higher densities of notonectids were found, with a greater impact during August and September. 


\section{Acknowledgements}

This research was performed at the Laboratory of Limnology, Biology Department of FFCLRP - University of São Paulo. We are grateful to RW Silva for help in the field, to AL Melo for identifying the notonectid, to the graduate students TCS Ferreira, FT Mise and BB Souza for discussions and ideas, and CAPES for a grant to AR Domingos. We also thank TF Domingues for reviewing the manuscript, as well as two anonymous reviewers for valuable suggestions.

\section{References}

ARCIFA, M.S., 2000. Feeding habits of Chaoboridae larvae in a tropical Brazilian reservoir. Brazilian Journal of Biology $=$ Revista Brasileira de Biologia, vol. 60, no. 4, pp. 591-597. http://dx.doi. org/10.1590/S0034-71082000000400008.

ARCIFA, M.S. and MESCHIATTI, A.J., 1993. Distribution and feeding ecology of fishes in a Brazilian reservoir: Lake Monte Alegre. Interciencia, vol. 18, no. 6, pp. 302-313.

ARCIFA, M.S., BUNIOTO, T.C., PERTICARRARI, A. and MINTO, W.J., 2013. Diel horizontal distribution of microcrustaceans and predators throughout a year in a shallow neotropical lake. Brazilian Journal of Biology $=$ Revista Brasileira de Biologia, vol. 73, no. 103, pp. 1-12. http://dx.doi.org/10.1590/S151969842013000100012. PMid:23644793.

ARCIFA, M.S., FERREIRA, T.C.S., FILETO, C., CASTILHONOLL, M.S.M., BUNIOTO, T.C. and MINTO, W.J., 2015. A long-term study on crustacean plankton of a shallow tropical lake: the role of invertebrate predation. Journal of Limnology, vol. 74 , no. 3, pp. 606-617.

ARCIFA, M.S., GOMES, E.A.T. and MESCHIATTI, A.J., 1992. Composition and fluctuations of the zooplankton of a tropical Brazilian reservoir. Archiv für Hydrobiologie, vol. 123, no. 4, pp. 479-495.

ARCIFA, M.S., MESCHIATTI, A.J. and GOMES, E.A.T., 1990. Thermal regime and stability of a tropical shallow reservoir: Lake Monte Alegre, Brazil. Revue d'Hydrobiologie Tropicale, vol. 23, no. 4, pp. 271-281.

ARNÉR, M., KOIVISTO, S., NORBERG, J. and KAUTSKY, N., 1998. Trophic interactions in rockpool food webs: regulation of zooplankton and phytoplankton by Notonecta and Daphnia. Freshwater Biology, vol. 39, no. 1, pp. 79-90. http://dx.doi. org/10.1046/j.1365-2427.1998.00262.x.

BAILEY, P.C.E., 1987. Abundance and age-specific spatial and temporal distribution in two waterbug species, Anisops deanei (Notonectidae) and Ranatra dispar (Nepidae) in three farm dams in south Australia. Oikos, vol. 49, no. 1, pp. 83-90. http://dx.doi. org/10.2307/3565557.

BAILEY, P.C.E., 2010. The effect of density and temperature on the swimming and aggregating behaviour of the backswimmer, Anisops deanei (Heteroptera:Notonectidae) and subsequent encounter rate with a sit-and-wait predator. Ethology, vol. 77, no. 1, pp. 44-57. http://dx.doi.org/10.1111/j.1439-0310.1988.tb00190.x.

BENNETT, D.V. and STREAMS, F.A., 1986. Effects of vegetation on Notonecta (Hemiptera) distribution in ponds with and without fish. Oikos, vol. 46, no. 1, pp. 62-69. http://dx.doi. org/10.2307/3565381.
BLAUSTEIN, L., 1998. Influence of the predatory backswimmer, Notonecta maculata, on invertebrate community structure. Ecological Entomology, vol. 23, no. 3, pp. 246-252. http://dx.doi. org/10.1046/j.1365-2311.1998.00138.x.

BROOKS, J.L., 1968. The effects of prey size selection by lake planktivores. Systematic Biology, vol. 17, no. 3, pp. 273-291. http://dx.doi.org/10.1093/sysbio/17.3.273.

BROOKS, J.L. and DODSON, S.I., 1965. Predation, body size, and composition of plankton. Science, vol. 150, no. 3692, pp. 28-35. http://dx.doi.org/10.1126/science.150.3692.28. PMid:17829740.

CASSANO, C.R., CASTILHO-NOLL, M.S. and ARCIFA, M.S., 2002. Water mite predation on zooplankton of a tropical lake. Brazilian Journal of Biology $=$ Revista Brasileira de Biologia, vol. 62, no. 4A, pp. 565-571. http://dx.doi.org/10.1590/S151969842002000400002. PMid:12659004.

CASTILHO-NOLL, M.S. and ARCIFA, M.S., 2007a. Chaoborus diet in a tropical lake and predation of microcrustaceans in laboratory experiments. Acta Limnologica Brasiliensia, vol. 19, no. 2 , pp. $163-174$

CASTILHO-NOLL, M.S. and ARCIFA, M.S., 2007b. Mesocosm experiment on the impact of invertebrate predation on zooplankton of a tropical lake. Aquatic Ecology, vol. 41, no. 4, pp. 587-598. http://dx.doi.org/10.1007/s10452-007-9112-4.

CLETO-FILHO, S.E.N. and ARCIFA, M.S., 2006. Horizontal distribution and temporal variation of the zoobenthos of a tropical Brazilian lake. Acta Limnologica Brasiliensia, vol. 18, no. 4 , pp. $407-421$

COOPER, S.D., 1983. Selective predation on cladocerans by common pond insects. Canadian Journal of Zoology, vol. 61, no. 4, pp. 879-886. http://dx.doi.org/10.1139/z83-115.

EITAM, A. and BLAUSTEIN, L., 2010. Effects of predator density and duration of predator occupancy on crustacean abundance and diversity in experimental pools. Hydrobiologia, vol. 652, no. 1, pp. 269-276. http://dx.doi.org/10.1007/s10750-010-0357-x.

ELLIS, R.A. and BORDEN, J.H., 1970. Predation by Notonecta undulata (Heteroptera: Notonectidae) on larvae of the yellow-fever mosquito. Annals of the Entomological Society of America, vol. 63, no. 4, pp. 963-973. http://dx.doi.org/10.1093/aesa/63.4.963.

FISCHER, S., PEREYRA, D. and FERNÁNDEZ, L., 2012. Predation ability and non-consumptive effects of Notonecta sellata (Heteroptera: Notonectidae) on immature stages of Culex pipiens (Diptera: Culicidae). Journal of Vector Ecology, vol. 37, no. 1, pp. 245-251. http://dx.doi.org/10.1111/j.1948-7134.2012.00223.x. PMid:22548560.

FISCHER, S., ZANOTTI, G., CASTRO, A., QUIROGA, L. and VARGAS, D.V., 2013. Effect of habitat complexity on the predation of Buenoa fuscipennis (Heteroptera: Notonectidae) on mosquito immature stages and alternative prey. Journal of Vector Ecology, vol. 38, no. 2, pp. 215-223. http://dx.doi.org/10.1111/j.19487134.2013.12033.x. PMid:24581348.

FOLTZ, S.J. and DODSON, S.I., 2009. Aquatic Hemiptera community structure in stormwater retention ponds: a watershed land cover approach. Hydrobiologia, vol. 621, no. 1, pp. 49-62. http://dx.doi.org/10.1007/s10750-008-9631-6.

GERGS, A. and RATTE, H.T., 2009. Predicting functional response and size selectivity of juvenile Notonecta maculata foraging on Daphnia magna. Ecological Modelling, vol. 220, no. 23, pp. 3331-3341. http://dx.doi.org/10.1016/j.ecolmodel.2009.08.012. 
GERGS, A., HOELTZENBEIN, N.I. and RATTE, H.T., 2010. Diurnal and nocturnal functional response of juvenile Notonecta maculata considered as a consequence of shifting predation behaviour. Behavioural Processes, vol. 85, no. 2, pp. 151-156. http://dx.doi.org/10.1016/j.beproc.2010.07.006. PMid:20637269.

GILBERT, J.J. and BURNS, C.W., 1999. Some observations on the diet of the backswimmer, Anisops wakefieldi (Hemiptera: Notonectidae). Hydrobiologia, vol. 412, pp. 111-118. http:// dx.doi.org/10.1023/A:1003812718853.

GILBERT, J.J., BURNS, C.W. and GILBERT, C.C., 1999. Summer distribution patterns of the backswimmer, Anisops wakefieldi (Hemiptera: Notonectidae), in a New Zealand pond. New Zealand Journal of Marine and Freshwater Research, vol. 33, no. 4, pp. 661-672. http://dx.doi.org/10.1080/00288330.1999.9516909.

GILLER, P.S. and MCNEILL, S., 1981. Predation strategies, resource partitioning and habitat selection in Notonecta (Hemiptera: Heteroptera). Journal of Animal Ecology, vol. 50, no. 3, pp. 789808. http://dx.doi.org/10.2307/4137.

HALL, D.J., COOPER, W.E. and WERNER, E.E., 1970. An experimental approach to the production dynamics and structure of freshwater animal communities. Limnology and Oceanography, vol. 15, no. 6, pp. 839-928. http://dx.doi.org/10.4319/lo.1970.15.6.0839.

HALL, D.J., THRELKELD, S.T., BURNS, C.W. and CROWLEY, P.H., 1976. The size-efficiency hypothesis and the size structure of zooplankton communities. Annual Review of Ecology and Systematics, vol. 7, no. 1, pp. 177-208. http://dx.doi.org/10.1146/ annurev.es.07.110176.001141.

HAMPTON, S.E., 2004. Habitat overlap of enemies: temporal patterns and the role of spatial complexity. Oecologia, vol. 138, no. 3, pp. 475-484. http://dx.doi.org/10.1007/s00442-003-1446-6. PMid:14666419.

HAMPTON, S.E. and GILBERT, J.J., 2001. Observations of insect predation on rotifers. Hydrobiologia, vol. 446/447, pp. 115-121. http://dx.doi.org/10.1023/A:1017543121353.

HAMPTON, S.E., GILBERT, J.J. and BURNS, C.W., 2000. Direct and indirect effects of juvenile Buenoa macrotibialis (Hemiptera: Notonectidae) on the zooplankton of a shallow pond. Limnology and Oceanography, vol. 45, no. 4, pp. 1006-1012. http://dx.doi. org/10.4319/1o.2000.45.4.1006.

HANAZATO, T. and YASUNO, M., 1989. Zooplankton community structure driven by vertebrate and invertebrate predators. Oecologia, vol. 81, no. 4, pp. 450-458. http://dx.doi.org/10.1007/BF00378951.

HIRVONEN, H., 1992. Effects of backswimmer (Notonecta) predation on crayfish (Pacifastacus) young: autotomy and behavioural responses. Annales Zoologici Fennici, vol. 29, pp. 261-271.

HURLBERT, S.H., 1984. Pseudoreplication and the design of ecological field experiments. Ecological Monographs, vol. 54, no. 2, pp. 187-211. http://dx.doi.org/10.2307/1942661.

JARA, F.G., PEROTTI, M.G. and DIÉGUEZ, M.C., 2012. Distribution of backswimmers in shallow ponds of Patagonia and their predatory role on a common tadpole-copepod assemblage. New Zealand Journal of Marine and Freshwater Research, vol. 46, no. 4, pp. 459-473. http://dx.doi.org/10.1080/00288330.20 12.707130

KERFOOT, W.C. and SIH,A., 1987. Predation: direct and indirect impacts on aquatic communities. Hanover: University Press of New England. 386 p.
LINDHOLM, M. and HESSEN, D.O., 2007. Competition and niche partitioning in a floodplain ecosystem: a cladoceran community squeezed between fish and invertebrate predation. African Zoology, vol. 42 , no. 2 , pp. $158-164$. http://dx.doi.org/10.3377/15627020(2007)42[158:CANPIA]2.0.CO;2.

MESCHIATTI, A.J. and ARCIFA, M.S., 2002. Early life stages of fish and the relationships with zooplankton in a tropical Brazilian reservoir: Lake Monte Alegre. Brazilian Journal of Biology = Revista Brasileira de Biologia, vol. 62, no. 1, pp. 41-50. http:// dx.doi.org/10.1590/S1519-69842002000100006. PMid:12185922.

MINTO, W.J., ARCIFA, M.S. and PERTICARRARI, A., 2010. Experiments on the influence of Chaoborus brasiliensis Theobald, 1901 (Diptera: Chaoboridae) on the diel vertical migration of microcrustaceans from Lake Monte Alegre, Brazil. Brazilian Journal of Biology $=$ Revista Brasileira de Biologia, vol. 70, no. 1, pp. 25-35. http://dx.doi.org/10.1590/S1519-69842010000100006. PMid:20231957.

MURDOCH, W.W. and SCOTT, M.A., 1984. Stability and extinction of laboratory populations of zooplankton preyed on by the backswimmer Notonecta. Ecology, vol. 64, no. 4, pp. 1231-1248. http://dx.doi.org/10.2307/1938330.

MURDOCH, W.W. and SIH, A., 1978. Age-dependent interference in a predatory insect. Journal of Animal Ecology, vol. 47, no. 2, pp. 581-592. http://dx.doi.org/10.2307/3802.

MURDOCH, W.W., SCOTT, M.A. and EBSWORTH, P., 1984. Effects of the general predator, Notonecta (Hemiptera) upon a freshwater community. Journal of Animal Ecology, vol. 53, no. 3, pp. 791-808. http://dx.doi.org/10.2307/4660.

NESBITT, L.M., RIESSEN, H.P. and RAMCHARAN, C.W., 1996. Opposing predation pressures and induced vertical migration responses in Daphnia. Limnology and Oceanography, vol. 41, no. 6, pp. 1306-1311. http://dx.doi.org/10.4319/lo.1996.41.6.1306.

NESSIMIAN, J.L. and RIBEIRO, J.R.I., 2000. Aspectos da biologia de Buenoa platycnemis (Fieber) (Insecta, Heteroptera, Notonectidae) da Restinga de Maricá, Rio de Janeiro. Revista Brasileira de Zoologia, vol. 17, no. 1, pp. 229-239. http://dx.doi. org/10.1590/S0101-81752000000100020.

PECKARSKY, B.L., 1982. Aquatic insect predator-prey relations. Bioscience, vol. 32, no. 4, pp. 261-266. http://dx.doi. org/10.2307/1308532.

QUIROZ-MARTÍNEZ, H. and RODRÍGUEZ-CASTRO, A., 2007. Aquatic insects as predators of mosquito larvae. Journal of the American Mosquito Control Association, vol. 23, no. 2, suppl., pp. 110-117. http://dx.doi.org/10.2987/8756-971X(2007 )23[110:AIAPOM]2.0.CO;2. PMid:17853601.

SAHA, N., ADITYA, G., SAHA, G.K. and HAMPTON, S.E., 2010. Opportunistic foraging by heteropteran mosquito predators. Aquatic Ecology, vol. 44, no. 1, pp. 167-176. http://dx.doi. org/10.1007/s10452-009-9250-y.

SCHILLING, E.G., LOFTIN, C.S. and HURYN, A.D., 2009. Macroinvertebrates as indicators of fish absence in naturally fishless lakes. Freshwater Biology, vol. 54, no. 1, pp. 181-202. http://dx.doi.org/10.1111/j.1365-2427.2008.02096.x.

SCOTT, M.A. and MURDOCH, W.W., 1983. Selective predation by the backswimmer, Notonecta. Limnology and Oceanography, vol. 28, no. 2, pp. 352-366. http://dx.doi.org/10.4319/lo.1983.28.2.0352.

SIH, A., 1982. Foraging strategies and the avoidance of predation by an aquatic insect, Notonecta hoffmanni. Ecology, vol. 63, no. 3, pp. 786-796. http://dx.doi.org/10.2307/1936799. 
STREAMS, F.A., 1987a. Within-habitat spatial separation of two Notonecta species: interactive $v s$. noninteractive resource partitioning. Ecology, vol. 68, no. 4, pp. 935-945. http://dx.doi. org/10.2307/1938365.

STREAMS, F.A., 1987b. Foraging behavior in a notonectid assemblage. American Midland Naturalist, vol. 117, no. 2, pp. 353-361. http://dx.doi.org/10.2307/2425977.

STREAMS, F.A., 1992. Age-dependent foraging depths of two species of Notonecta (Heteroptera: Notonectidae) breeding together in a small pond. Aquatic Insects, vol. 14, no. 3, pp. 183-191. http:// dx.doi.org/10.1080/01650429209361481.

WALSH, E.J., SALAZAR, M., REMIREZ, J., MOLDES, O. and WALLACE, R.L., 2006. Predation by invertebrate predators on the colonial rotifer Sinantherina socialis. Invertebrate Biology, vol. 125, no. 4, pp. 325-335. http://dx.doi.org/10.1111/j.17447410.2006.00064.x

ZARET, T.M., 1980. Predation and freshwater communities. New Haven: Yale University Press. 187 p. 